in the tropics generally, and that representatives of some of the better known genera are scanty or absent. Corner's evidence is to the effect that larger fungi are abundant numerically as well as specifically and generically, but that "their fructifications are seasonal, developing quickly and rotting quickly, during the first rains which follow dry weather, and that if one is not able to visit the forest daily during the right fortnight, no trace of these fungi will be found. As for variety, I have found in Singapore some sixty species of Boletus, twenty-six species of Russula, twenty species of Hygrophorus, etc., etc." The evidence, in brief, gives a clear indication that tropical conditions are by no means unsuitable for the higher Basidiomycetes, but that the collector must be on the spot at precisely the right time.

\section{Health of Zanzibar}

IN his latest report, Dr. S. W. T. Lee, senior medical officer in charge, Zanzibar, shows that the health services for women and children are improving. The women's clinic is attended by $150-200$ patients daily, and in four dispensaries in the country the same work is carried on. Routine medical and dental treatment is given to school children, who all suffer, however, from nutritional defects. School feeding in certain places over a period of three months resulted in improved weight, height and health, but the Government is unable to finance the adequate treatment of all school children. The work of ante-natal clinics has steadily increased, and out of nearly 1,300 cases there was only one death which was due to puerperal sepsis.

\section{Dr. George Oliver, I84I-I9I5}

Dr. George Oliver, a well-known consultant physician and an authority on the examination of the blood and circulation, was born at Middleton-inTeesdale, Durham, on April 13, 1841, the son of a surgeon. He received his medical education at University College, London, where he came under the influence of Dr. William Sharpey, the professor of physiology, and University College Hospital. $\mathrm{He}$ qualified M.B. London in 1865, and in 1873 obtained a gold medal at the M.D. London examination. Eventually he settled in Harrogate and soon acquired an extensive practice. In 1887 he was elected a fellow of the Royal College of Physicians of London, before which he delivered the Croonian Lecture in 1896, and in 1904 founded the Oliver-Sharpey lectureship in honour of his old master, the object of which was "to promote physiological research by observation and experiment, and to encourage the application of physiological knowledge to the prevention and cure of disease and the prolongation of life". Oliver's aim throughout his career was to make medicine a more exact science than it had been hitherto, especially as regards the blood and circulation; and with that end in view he invented several instruments such as the hæmoglobinometer, hæmodynamometer and arteriometer. He also devoted much attention to the study of the glands of internal secretion, especially the supra- renals, in conjunction with Prof. Schäfer. He died at Farnham, in Surrey, where he had been living in retirement for some years, on December 27, 1915 .

\section{Institution lof Chemical Engineers: Medal Awards}

The following awards were presented at the nineteenth annual corporate meeting of the Institution of Chemical Engineers held on April 4: Osborne Reynolds Medal : Mr. M. B. Donald, lecturer in (and at present in charge of) chemical engineering at University College, London, and joint honorary secretary of the Institution of Chemical Engineers, for meritorious services to the Institution during the year 1940 ; Moulton Medal : Mr. J. C. Farrant, of International Combustion Lfd., for his paper, "A Review of Certain Unit Processes in the Reduction of Materials"; Junior Moulton Medal and Award : Mr. S. A. Gregory, of Moussec Ltd., for his paper, "Plant Design in Microbiological Processes" ; William Macnab Medal : Mr. J. V. S. Glass, of the CastnerKellner Alkali Co. Ltd., for the best set of answers submitted in the 1940 associate-membership examination of the Institution.

\section{Announcements}

WE regret to announce the following deaths :

Prof. Herbert Freundlich, For. Mem. R.S., professor of colloidal chemistry in the University of Minnesota since 1938, on March 29, aged sixty-one.

Commandant J. G. Hackin, of the Free French Forces, formerly professor of archæology and Indian art in the Ecole du Louvre, Paris, by enemy action, aged fifty-four.

Prof. A. Lapworth, F.R.S., emeritus professor of chemistry in the University of Manchester, on April 5, aged sixty-eight.

Prof. J. S. Macdonald, F.R.S., emeritus professor of physiology in the University of Liverpool, on March 29, aged seventy-three.

THE forty-seventh James Forrest Lecture of the Institution of Civil Engineers will be delivered by Prof. E. N. da C. Andrade, Quain professor of physics in the University of London, on April 29. Prof. Andrade will discuss "The Mechanical Behaviour of Solids".

Following a long and severe illness, Lieut.Colonel W. A. Vignoles has been obliged to relinquish his appointment as senior managing director of Messrs. Evershed and Vignoles, Ltd. Mr. J. C. Needham succeeds him in that capacity, and Mr. M. Vines and Mr. D. D. Walker have been appointed additional managing directors. Colonel Vignoles worked as an apprentice with the predecessors of the Company, W. T. Goolden and Co., joining that firm nearly fifty years ago in the autumn of 1891 .

Dr. Herald R. Cox, principal bacteriologist of the United States Public Health Service, has been unanimously nominated by the Theobald Smith Award Committee to receive the 1940 Theobald Smith award, consisting of a bronze medal and a sum of $£ 200$, for his outstanding research on Rickettsia diseases. 